\title{
Morphology and Composition of Chromite Macrocrysts and their Inclusions, Guaniamo Kimberlite Field, Venezuela
}

\author{
K. M. Barron $(1)$, A.M. Logvinova $(2)$, N.V. Sobolev (2) \\ 1.) $\mathbf{5 6}$ Hartford Trail, Brampton, Ontario, Canada L6W 4J8 \\ 2.) United Institute of Geology, Geophysics \& Mineralogy, Universitetsky pr. 3, Novosibirsk 90, 630090 Russia
}

Since 1982, more than 20 shallow-dipping hypabyssal kimberlite sills have been discovered near the Quebrada Grande, a tributary of the Rio Guaniamo, in SW Estado Bolivar, Venezuela. The majority of discoveries were made by artisanal miners through overdeepening of alluvial pits by hydraulic mining or were exposed in hand-dug vertical shafts. The Guaniamo kimberlites are all diamondiferous to some degree. Micro- and macrodiamonds $(>0.5 \mathrm{~mm})$ can be recovered from the majority of kimberlite exposures and overall grades are thought to be locally in excess of 1.5 carats per tonne (Nixon et al. 1994). While there are several studies of pyrope garnets from the Guaniamo kimberlite field (Nixon $e t$ al. 1992, 1994; Meyer and McCallum, 1993) there are no comprehensive studies of chromites (chromium spinels).

Herein are presented the results of a study of chromites retrieved from heavy mineral concentrates prepared from several saprolitised kimberlites. The grains range in size from 0.25 to 1.0 $\mathrm{mm}$, and are rarely larger. Chromites are easily recognized by their faceted octahedral shapes,-with rounded and slightly resorbed faces and a typical brushed metal lustre. In addition, garnet and olivine inclusions were extracted by crushing from selected chromite macrocrysts. Indicator mineral garnet populations differ significantly between individual sills. Chromite populations show correspondingly less variability. There are also differences in the morphology (size, colour and crystal form) of recovered diamond populations and anecdotal evidence of variable diamond grades. This implies that each sill represents a discrete mantle sampling, and a separate intrusive event, and that the sills are not part of one interconnected body as previously suggested by Nixon et al. (1992).

Chromites typically appear homogeneous in electron backscatter imaging, however there are rare examples where cores are mantled by compositionally slightly higher $\mathrm{Cr}_{2} \mathrm{O}_{3}$ and very low $\mathrm{Al}_{2} \mathrm{O}_{3}$ (1.67$2.36 \%$ ) rims. These may be a product of reaction with kimberlite magma or a pre-emplacement metasomatic event. Many of the microprobe analyses are close to or within diamond inclusion and intergrowth compositional fields. Chromites with low $\mathrm{Al}_{2} \mathrm{O}_{3}$ and $>62 \% \mathrm{Cr}_{2} \mathrm{O}_{3}$ are considered significant indicators of diamond content (Sobolev, 1977). High proportions of Guaniamo chromites plot compositionally within the $\mathrm{Cr}_{2} \mathrm{O}_{3}-\mathrm{TiO}_{2}-\mathrm{Al}_{2} \mathrm{O}_{3}$ inclusion fields of chromites encapsulated in Russian diamonds (Sobolev et al., 1993) and the fields of Fipke et al. (1995), but have lower MgO contents than fields portrayed on $\mathrm{MgO}$ vs. $\mathrm{Cr}_{2} \mathrm{O}_{3}$ plots of Gurney and Zweistra (1995) and Fipke et al. (1995).

As part of this study, fourteen inclusion-bearing chromites were selected from a population of 350 grains recovered from the Desayuno-2 kimberlite. The inclusion-bearing chromites demonstrate narrow variations in chromium, but wider variations in $\mathrm{MgO}(10.7-13.0 \mathrm{wt} \%)$. A total of 10 olivine and 4 garnet inclusions were recovered. One chromite grain (Ven-19) yielded two garnet grains of different composition, mostly in respect of $\mathrm{Cr}$ content. Both lherzolitic and harzburgitic parageneses are represented. Temperature estimates for co-existing olivine-chromite pairs were calculated using the method of O'Neill and Wall (1987). Results indicate equilibration temperatures of $800-1000^{\circ} \mathrm{C}$. This result is nearly identical with results of nickel thermometry on lherzolitic and harburgitic Guaniamo garnets by Nixon et al. (1994) which yielded temperatures predominantly in the range $850-1000^{\circ} \mathrm{C}$. Both results are lower than the $870-1280^{\circ} \mathrm{C}$ derived from 30 bimineralic garnet and clinopyroxene Guaniamo diamond inclusions of eclogitic paragenesis by Sobolev et al. (this volume).

These estimates suggest that diamond formation may be at higher temperatures, and potentially 
spatially isolated from peridotite domains. The evidence that diamond inclusion populations from Guaniamo overwhelmingly reflect eclogitic parageneses ( $99.4 \%$ E-type, Sobolev et al., this volume) is highly enigmatic. Eclogitic indicator minerals are extremely rare at Guaniamo. This may be an artefact of tropical weathering, which tends to strip pyroxenes and calcic almandine pyropes from saprolitic horizons. A corresponding rarity of eclogitic minerals in fresh kimberlite rock has still to be confirmed, however preliminary observations from diamond drill core suggest that such is the case. The dearth of chromite and subcalcic pyrope garnet inclusions in diamonds is also unexplained. An abundance of such inclusions would be expected given the favourable numbers of Guaniamo chromite and harburgitic garnets with worldwide "inclusion type" chemistries. Only two chromite inclusions have been recovered (Sobolev et al., this volume). These results call into question the practice of using indicator minerals to forecast the diamond grades of kimberlite bodies, since here the favourable indicator minerals observed appear to be only marginally represented in the zone of diamond genesis, though paradoxically, the forecasted high grade nature of the kimberlites is borne out by results of mining. A further interesting feature of the Guaniamo kimberlites is the complete lack of ilmenite or garnet from the megacrystic (discrete nodule) suite.

The Guaniamo area is possibly underlain by an unusual mantle stratigraphy. It is relatively close to the northern edge of the Guiana Shield in a "Proton" (Janse and Sheahan, 1995) and not in the thicker Archean nucleus of the craton where diamondiferous kimberlites are conventionally expected to occur. The field follows the Cabruta-Uraicoera shear zone, which extends from the craton margin at the Rio Orinoco, south-southeast into Brazil. The Cabruta shear may be a mobile zone, similar to that which hosts the Argyle lamproite. The presence of numerous sills, given the current deep level of erosion, is also intriguing. A lack of cap rocks which could have impeded the upward passage of kimberlite magma to form the sills, suggests that the kimberlites were emplaced into an unusual tectonic stress regime.

\section{References}

Fipke, C.E., Gurney, J.J., Moore, R.O., 1995. Diamond exploration techniques emphasising indicator mineral geochemistry and Canadian examples. Geol. Surv. Canada, Bulletin 423

Gurney, J.J., Zweistra, P., 1995. The interpretation of the major element compositions of mantle minerals in diamond exploration. J. Geochem. Exploration 53:293-309

Janse, A.J.A., Sheahan, P.A., 1995. Catalogue of world wide diamond and kimberlite occurrences: a selective and annotative approach. J. Geochem. Exploration 53: 73-111

Logvinova, A.M., Sobolev, N.V., 1995. Morphology and composition of mineral inclusions in chromite macrocrysts from kimberlites and lamproites. p.331-332 Extended Abstr. Vol., 6th Intl. Kimberlite Conf., Novosibirsk, Russia, 1995

Meyer, H.O.A., McCallum, M.E., 1993. Diamonds and their sources in the Venezuelan portion of the Guyana Shield. Econ. Geol. 88:989-998

O'Neill, H.St.C., Wall, W.J., 1987. The olivine-orthopyroxene-spinel oxygen geobarometer, the nickel precipitation curve and the oxygen fugacity of the Earth's upper mantle. Jour. Petrol. 28:1169-1191

Nixon, P.H., Davies, G.R., Rex, D.C., Gray, A. 1992. Venezuelan kimberlites. Jour. Volcanology Geotherm. Research $50: 101-115$

Nixon, P.H., Griffin, W.L., Davies, G.R, Condliffe, E., 1994. Cr-garnet indicators in Venezuelan kimberlites and their bearing on the evolution of the Guyana Craton. p. 378-387 In Proc. 5th Intl. Kimberlite Conf., Araxá, Brazil, 1991. CPRM Special Publication 1A, Brasilia

Sobolev, N.V., 1977. Deep-seated inclusions in kimberlites and the problem of the composition of the upper mantle. Amer. Geophys. Union, Washington, D.C., 279 pp.

Sobolev, N.V., Pokilenkho, N.P., Afanas'ev, V.P., 1993. Kimberlitic pyrope and chromite morphology and chemistry as indicators of diamond grade in Yahutian and Arkhangelsk Provinces. p. 63-72 In Wid-Continent Diamonds, GAC-MAC Symposium Volume, May 17-18, 1993, Edmonton, Afberta.

Sobolev, N.V., Yefimova, E.M., Channer, D., Anderson, P.F.N., Barron, K.M., 1998. A unique eclogitic source of Guaniamo diamonds, Guyana Shield, Venezuela. (this volume) 
Desengaño $(n=162)$
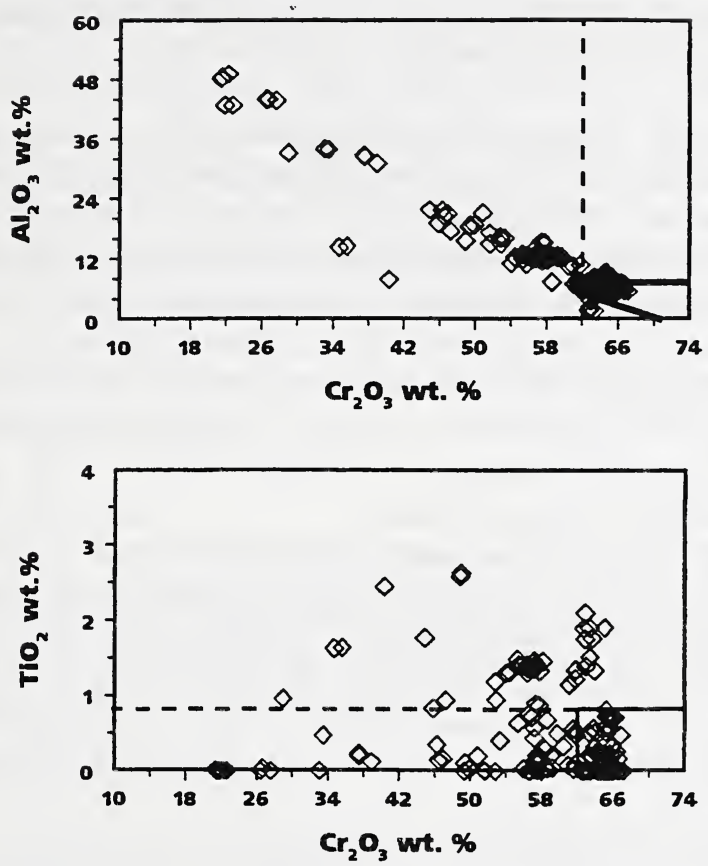

La Peinilla del Diablo $(n=34)$
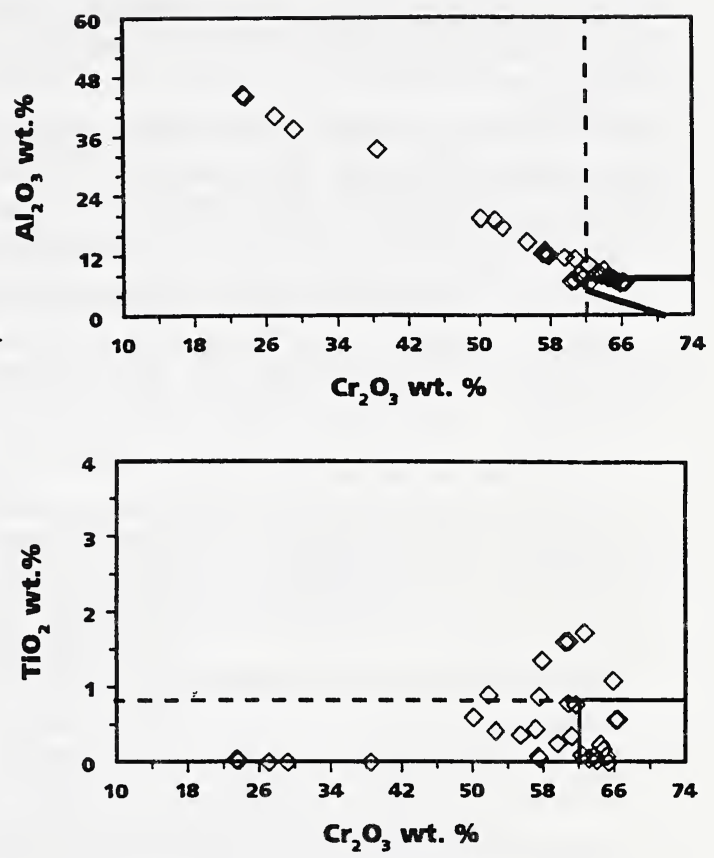

$\mathrm{Al}_{2} \mathrm{O}_{3}$ vs. $\mathrm{Cr}_{2} \mathrm{O}_{3}$ and $\mathrm{TiO}_{2}$ vs. $\mathrm{Cr}_{2} \mathrm{O}_{3}$ plots for chrome spinels from concentrates

Garnet Inclusions from chromites

+ rakutha

$\triangle$ Elbondalo a

O Nowlonds.

a Plonerskaya

$\square$ Lomonosovskaya 8

$\checkmark$ Guanlamo

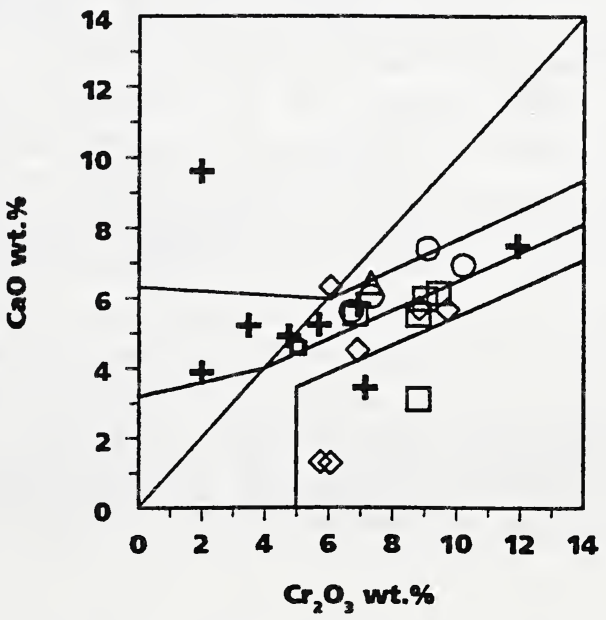

Composition of garnet inclusions from chromites 